\title{
"A Clinical Study To Evaluate The Efficacy Of Shatapushpa Tail Uttarbasti \& Shatavari Tail Uttarbasti With Herbal Compound In The Treatment Of Anovulatory Cycle"
}

\author{
* Dr.Bhagyashri Mahavir Khot. Dr.Meenal Dipak Lad. ${ }^{1}$ Dr.Arun Jagannath \\ Patil $^{2}$. Dr.Anil Chindhu kakad ${ }^{3}$. \\ *(Asso.Professor-Streerog-Prasutitantra Dept.R.A.Podar Medical CollegeWorli Mumbai.). \\ (Prof. \&Head Dravyaguna Dept.College Of Ayurved AndResearch Center Nigadi. $)^{1}$ \\ (Asso. Professor-Streerog-Prasutitantra Dept.R.A.Podar Medical College Worli Mumbai) ${ }^{2}$ \\ (P.G.Scholar Streerog-Prasutitantra Dept.R.A.Podar Medical College Worli Mumbai. $)^{3}$
}

\begin{abstract}
Absract-Infertility is major health problem.The rate of infertility is steadily increasing due to change in life style.High pollution, socioeconomic cause,enormous amount of stress.Among many causes of infertility the anovulation is very common problem in approximately $40 \%$ cases of female infertility.Majority of these cases could be treated either hormonal therapy or surgical intervention.This study will emphasize on careful holistic approach in management of anovulatory cycles.60 patients were completed clinical trial.30 patient in Group A treated with Shatapushpa Tail Uttarbasti with Herbal Compound and 30 patient Group in B treated with Shatavari Tail Uttarbasti with Herbal Compound for three month.The subjective and objective parameters were measured before and after treatment in each group.Group A and Group B showed induces timely ovulation, increase endometrial thickness and menstrual flow.But menstrual pain is insignificant in Group B.
\end{abstract}

Key Words-Shatpushpa \&Shatavari Tail Uttarbasti,Herbal Compound,Anovulatory Cycle.

\section{Introduction-}

Motherhood is described as the pleasing punishment to woman. God "The creator" has empowered every human being to reproduce itself. The function of reproduction is the noblest. God has given this magnanimous gift only to woman. The "DESIRE" of women for "CHILDREN" is sometimes stronger than self interest in beauty and figure, and may be stronger than the claims of career. The children cement a marriage. Infertility is becoming a major health problem,this infertility condition has deep impact on individuals physical and mental health and disturbs her family life.The treatment suggested in modern science is though effective,has lots of side effects.

Ayurveda is ancient medicine system which originated in india thousand of years ago.In ayurveda we find this topic of infertility described under the heading of 'vandhyatva`.so this burning issue of the society is selected for the study.ovarian factor are most common cause of infertility,contributing $25-35 \%$.

In ayurveda, to achieve pregnancy sushruta has given four essential factors rutu (fertile period), kshetra (healthy reproductive organs), ambu (proper nutrient fluid), beeja (ovum/ sperm) in this four factor, one important factor is 'beeja', which directly related to ovulation process ${ }^{2}$. Defect in any one of them can cause vandhyatva. ${ }^{2}$

The saying, "as you sow, so shall you reap" signifies the importance of the seed. It is the seed which gives the fruit and so it is the beeja which yields the garbha. And the absence of this beeja in women is termed as anovulation.

Acharya sushuta has mentioned the impotance of uttarbasti in aartavadosha and agney gunatmak dravyas act on ovulation.

Taking into consideration of infertility many woman suffering from anovulatory cycles.It present with irregular,frequent, scanty menses and infertility.therefore this topic was selected for clinical study.

\section{Aims and Objectives-}

\section{Aims-}

To find the effects of the drug on the ovulation (Beejotsarga)

Objectives-

- $\quad$ To study to propose the probable mechanism of action of the study drug on anovulatory cycles.

- $\quad$ To study in detail Ayurvedic and modern literature regarding Vandhyatva and study drug.

- $\quad$ To find the effect of the drug on endometrium (Garbhashayya)

- To study the complications if any during the course of treatment.I 
A. Materials -

III. Materials and Methods-

\section{Literature}

All available Ayurvedic classics and modern available texts, magazines, journals, M.D. Dissertations, Research Papers and internet were referred for the complete review of the literature.

\section{Material \& Method-}

Attending OPD Stri-rog \& Prasutitantra,M.A.Podar Ayurved Medical Hospital,Detailed history of patient was taken covering high risk behaviors, Modes of transmission presenting complaint and physical examination.After a written informed consent,approval of institutional ethical committee was taken.

\section{Inclusion Criteria-}

- $\quad$ Married patients(Age group 20-40yrs)

- Infertility patient

- P.C.O.D.

- Irregular menses / scanty menses due to anovulatory cycle

- Anovulatory cycle

- Delayed ovulation.

\section{Exclusion Criteria-}

- Unmarried patients

- Bleeding P/V

- $\quad$ Cervical tumour, polyp, Ca cervix

- Uterine fibroid

- $\quad$ Congenital anomalies in female genital tract

- Tubercular endometritis

- $\quad$ HIV/VDRL/HbsAg positive

- Malignant diseased patients and cytotoxic patients.

\section{Discontinous Criteria-}

- An acute or severe illness.

- Patient left against medical advice.

\section{Grouping Of The Patient-}

Group A - 30 patients of anovulatory cycle were given Shatapushpa tail Uttarbasti with Herbal compound.

Group B - 30 Patients with anovulatory cycle were given Shatavari tail Uttarbasti with Herbal compound.

Dosage-Intrauterine Uttarbasti $5 \mathrm{cc}$ for successive 5 days after cessation of menstruation, it was repeated for 3 month and oral herbal compound 2 gm (4 Tablet) were given in two times a day.Suggest for taking in morning empty stomach and in evening given two hours before taking meal with water.

Drugs-Shatpushpa (Anthem sowa), Shatavari (Aspergus racemosus),Trikatu(Zingiber officinale,Piper longum,Piper nigrum), Aswagandha(Withania somnifera),Jeerak (cumium cymium), Kanchnar (Bauhnia variegata),Gudmar (gymnema sylvestris),Rason(Alum sativum).

Raw material were purchased directly from the market.The drugs were checked for the authenticity. Taila was prepared by standard method given in kashypa samhita.

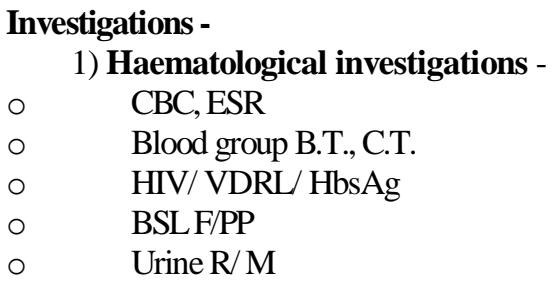

\section{USG pelvis}


3. Follicular study- A serial vaginal or abdominal sonography was done from $10^{\text {th }}$ day of menstrual cycle, till after ovulation.

A) Subjective Criteria:-

1) Irregularity of menses -

$$
\begin{aligned}
& \text { Regular - Grade } 0 . \\
& \text { Irregular-Grade } 1 .
\end{aligned}
$$

2) Quantity of Bleeding:-

\begin{tabular}{|l|l|l|}
\hline Grade & Amount of bleeding \\
\hline 0 & Spotting & \\
\hline 1 & Scanty & $1-2$ pads/day \\
\hline 2 & Moderate & $2-3$ pads/day \\
\hline 3 & Excessive & $4-5$ pads/day \\
\hline
\end{tabular}

B) Objective Criteria:-

1) Follicular Size -

\begin{tabular}{|l|l|}
\hline Grade & Follicular size \\
\hline 0 & $<12 \mathrm{~mm}$ \\
\hline 1 & $12-20 \mathrm{~mm}$ \\
\hline 2 & $>20 \mathrm{~mm}$ \\
\hline 3 & Ovulated \\
\hline
\end{tabular}

2) Endometrial Thickness-

\begin{tabular}{|l|l|}
\hline Grade & Endometrial thickness \\
\hline 0 & $<5 \mathrm{~mm}$ \\
\hline 1 & $5-7 \mathrm{~mm}$ \\
\hline 2 & $7-9 \mathrm{~mm}$ \\
\hline 3 & $>9 \mathrm{~mm}$ \\
\hline
\end{tabular}

\section{Total effect of Treatment-}

The overall effect will be graded into 5 types-

- Unchanged

- Improved

- Complete remission

- Conceived

Unchanged - No improvement .

Improved - Ovulation not occurred but only improvement in the size of follicles means $\geq 12-20 \mathrm{~mm}$

Complete remission - ovulation occurred with the follicular size $\geq 20 \mathrm{~mm}$

Conceived -The patient's husband otherwise normal was conceived after the treatment.

Observations And Results-

Age wise distribution of patients -(Table 1)-

\begin{tabular}{|l|l|l|l|l|}
\hline \multirow{2}{*}{$\begin{array}{l}\text { Age group } \\
\text { (in years) }\end{array}$} & No Of Pts. & $\begin{array}{l}\text { Total } \\
\text { (Out of } 60\end{array}$ & $\%$ \\
\cline { 2 - 5 } Patient) & Group A & Group B & 3 & 5 \\
\hline $20-25$ & 1 & 2 & 20 & 33.3 \\
\hline $26-30$ & 9 & 11 & 31 & 51.6 \\
\hline $31-35$ & 16 & 15 & 6 & 10 \\
\hline $36-40$ & 4 & 2 & & \\
\hline
\end{tabular}

Age group was divided into four groups.patient above the age of $20 \mathrm{yr}$ taken up for study.3 patients out of 60 (5\%)belonged to the age group of 20-25 yr. 20 patients out of 60 (33.3\%) belong to age group of 26-30 yr.31 patients (51.6\%) belonged to the age group of 31-35 yrs.\&6 patients (10\%)belonged to age group of $36-40$ years.

Distribution of patients by Type of infertility -(Table 2) 
"A clinical study to evaluate the efficacy of shatapushpa tail uttarbasti \& shatavari tail uttarbasti

\begin{tabular}{|c|c|c|c|c|}
\hline \multirow{2}{*}{ Type of infertility } & \multicolumn{2}{|c|}{ No Of Pts. } & \multirow{2}{*}{$\begin{array}{l}\text { Total(Out of } 60 \\
\text { Patient) }\end{array}$} & \multirow{2}{*}{$\%$} \\
\hline & Group A & Group B & & \\
\hline Primary & 24 & 25 & 49 & 81.6 \\
\hline Secondary & 6 & 5 & 11 & 18.3 \\
\hline
\end{tabular}

Out of 60 patients observed $49(81.6 \%)$ patients were having Primary infertility and $11(18.3 \%)$ patients were of secondary infertility.

Distribution of patients by Prakruti -(Table 4)

\begin{tabular}{|l|l|l|l|l|}
\hline \multirow{2}{*}{ Prakruti } & No Of Pts. & \multirow{2}{*}{$\begin{array}{l}\text { Total(Out of 60 } \\
\text { Patient) }\end{array}$} & \multirow{2}{*}{} \\
\cline { 2 - 5 } & Group A & Group B & 13 & 21.6 \\
\hline Vata-Pitta & 4 & 9 & 16 & 26.6 \\
\hline Vata-Kapha & 11 & 5 & 9 & 15 \\
\hline Pitta-Vata & 7 & 2 & 7 & 11.6 \\
\hline Pitta-Kapha & 3 & 4 & 8 & 13.3 \\
\hline Kapha-Vata & 2 & 6 & 7 & 11.6 \\
\hline Kapha-Pitta & 3 & 4 & 16 & 16 \\
\hline
\end{tabular}

Out of 60 patient observed 13 (21.6\%)had Vata-Pitta prakruti,16 patients $(26.6 \%)$ had vat-kapha prakruti,9 patients (15\%)had pitta-vata prakruti,7 patients(11.6\%)had pitta-kapha prakruti,8 patient $(13.3 \%)$ had kapha-vata prakruti, 7 patients $(11.6 \%)$ had kapha pitta prakruti.

This shows that anovulatory cycle is commonly seen in patient with vata-kapha and vata-pitta prakruti.

Distribution of patients by causes of Anovulation -

\begin{tabular}{|c|c|c|c|c|}
\hline \multirow{2}{*}{ Anovulation } & \multicolumn{2}{|c|}{ NO OF Pts. } & \multirow{2}{*}{ TOTAL } & \multirow{2}{*}{$\%$} \\
\cline { 2 - 3 } & GROUP A & GROUP B & & 21.6 \\
\hline PCOD & 6 & 7 & 13 & 10 \\
\hline Delayed Ovulation & 2 & 4 & 6 & 71.6 \\
\hline Unexplained & 22 & 21 & 43 & \\
\hline
\end{tabular}

Out of 60 patients observed 13 (21.6\%)patients were having PCOD,6 patients (10\%)patients were having delayed ovulation and cause of anovulation in 43(71.6\%)patients was unexplainatory.

$77 \%$ patients had not any history of major disease.9\%patients had history of hypertension.62\% of patients were kroor koshti and $38 \%$ were mrudu koshti.the apan vayu dushti was found in 77\%patients either by atipravrit or by apravriti.We observed that most of patients in habbit of Vishamashan 69\%,Samshan is $49 \%$,Ajeernashan $67 \%$ and almost all categaries of Avidhi aahar was found in patients. Maximum number of patients were practicing the vatic ahara,but the paittik and shlaishmik ahara was also taken by the patients much amount.This shows all tridoshas can prouduce the disease in predominance of vata.pragvat sevan,vegasandharan,ati adhyayan,atishram,atyadhwa gaman and abhyang dwesha were prominent.These are main etiological factor which aggrevate disease.

\section{Statistical Analysis-}

After statistical Analysis of effect of therapy on subjective \& objective parameters Group A by Wilcoxon Signed rank test.

\begin{tabular}{|c|c|c|c|c|c|c|c|c|c|}
\hline Sr.No. & Symptom & & Mean & SD & SE & $\mathrm{W}$ & $\mathrm{n}$ & $\mathrm{Z}$ & $\mathrm{P}$ \\
\hline 1) & $\begin{array}{l}\text { Follicular } \\
\text { size. }\end{array}$ & $\begin{array}{l}\text { BT } \\
\text { AT } \\
\text { DIFF }\end{array}$ & $\begin{array}{l}1.12 \\
2.42 \\
-1.30\end{array}$ & $\begin{array}{l}0.89 \\
1.11 \\
1.44\end{array}$ & 0.26 & $\begin{array}{l}- \\
303\end{array}$ & $\begin{array}{l}- \\
27\end{array}$ & 3.58 & $\begin{array}{l}<0.0001 \\
\text { Extremely } \\
\text { Significant. }\end{array}$ \\
\hline 2) & $\begin{array}{l}\text { Endometrial } \\
\text { Thickness }\end{array}$ & $\begin{array}{l}\text { BT } \\
\text { AT } \\
\text { DIFF }\end{array}$ & $\begin{array}{l}1.7 \\
2.3 \\
-0.5 \\
\end{array}$ & $\begin{array}{l}0.60 \\
0.71 \\
0.92 \\
\end{array}$ & $\begin{array}{l}0.10 \\
0.12 \\
0.16 \\
\end{array}$ & $\begin{array}{l}- \\
162 \\
\end{array}$ & 20 & 2.72 & $\begin{array}{l}<0.01 \\
\text { Very } \\
\text { significant }\end{array}$ \\
\hline 3) & $\begin{array}{l}\text { Menstual } \\
\text { Flow }\end{array}$ & $\begin{array}{l}\text { BT } \\
\text { AT } \\
\text { DIFF }\end{array}$ & $\begin{array}{l}1.21 \\
1.66 \\
-0.47\end{array}$ & $\begin{array}{l}0.62 \\
0.72 \\
0.72\end{array}$ & $\begin{array}{l}0.11 \\
0.14 \\
0.13\end{array}$ & 132 & 19 & 2.66 & $\begin{array}{l}0.01 \\
\text { Very } \\
\text { significant. }\end{array}$ \\
\hline 4) & $\begin{array}{l}\text { Menstual } \\
\text { pain }\end{array}$ & $\begin{array}{l}\text { BT } \\
\text { AT } \\
\text { DIFF }\end{array}$ & $\begin{array}{l}1.86 \\
1.29 \\
0.58\end{array}$ & $\begin{array}{l}0.85 \\
0.64 \\
0.85 \\
\end{array}$ & $\begin{array}{l}0.15 \\
0.12 \\
0.16\end{array}$ & 170 & 22 & 2.74 & $\begin{array}{l}<0.01 \\
\text { Very } \\
\text { significant }\end{array}$ \\
\hline
\end{tabular}


Analysis of effect of therapy on subjective \& objective parameters Group B by Wilcoxon Signed rank test. In Group A-

\begin{tabular}{|l|l|l|l|l|l|l|l|l|l|}
\hline Sr.No. & Symptom & & Mean & SD & SE & W & n & Z & P \\
\hline 1$)$ & Follicular & BT & 1.1 & 0.87 & 0.16 & & & & $<0.0001$ \\
& size. & AT & 2.4 & 1.1 & 0.22 & -300 & - & 2.87 & Extremely \\
& & DIFF & -1.3 & 0.76 & 0.16 & & 21 & & Significant. \\
\hline 2$)$ & Endometrial & BT & 1.85 & 0.76 & 0.13 & & & & $<0.01$ \\
& Thickness & AT & 2.39 & 0.84 & 0.15 & -158 & 22 & 2.57 & Very \\
& & DIFF & -5.32 & 0.93 & 0.17 & & & & significant \\
\hline 3$)$ & Menstual & BT & 1.4 & 0.66 & 0.12 & & & & 40.00 \\
& Flow & AT & 1.7 & 0.60 & 0.10 & -165 & 21 & 2.87 & Highly \\
& & DIFF & -0.6 & 0.69 & 0.12 & & & & significant. \\
\hline 4$)$ & Menstual & BT & 1.71 & 0.78 & 0.15 & & & & 70.05 \\
& pain & AT & 1.51 & 0.75 & 0.13 & 40 & 15 & 1.12 & Not \\
& & DIFF & 1.67 & 0.71 & 0.12 & & & & significant \\
\hline
\end{tabular}

At the end of treatment it was seen that $74.19 \%$ of patient had ovulated.5.59\% of patients had conceived and endometrial thickness $54.37 \%$ of patient were increased.follicular size $14.01 \%$ of patient were increased.

Painless cycle were obtained in $76.67 \%$ of the patient.The menstrual flow is normal in $72.79 \%$ of patient.

\section{In group B-}

At the end of treatment it was seen that $73.89 \%$ of patient had ovulated.9.29\%of patients had conceived and endometrial thickness $54.67 \%$ of patient were increased.follicular size $11.59 \%$ of patient were increased.

Painless cycle were obtained in $37.19 \%$ of the patient..The menstrual flow is normal in $52.09 \%$ of patient. Intergroup comparison of Group A with Group B(Man Whitney U test) showed statistically very significant result in improving menstrual pain in Group A than in Group B.But all other profile were found significant in both group.

\section{Probable Mode Of Action Of Shatpushpa And Shatavari Tail-}

Vandyatva due to anovulation is vata-kapha pradhan vyadhi.In case of avaranatmak samprapti it is vata pitta pradhan vyadhi. In case of kshayatmak samprapti it is vikruti of vata dosha.(i.e.Apan vayu karmatah hani)occurs.Hence the treatment be vata kaphashamak,agnidipan,pachak and vatanulomaka and brihan.

The probable mechanism of the shatpushpa and shatavari tail is synergistic action between siddha tail of the uttarbasti.Uttarbasti is the procedure through which the drug is instilled into the uterus.Uterus is the mulasthan of artava vaha srotasa. The drug being directly instilled in the uterus gives direct access to the seat of strotovaigunya and dosha -dushya-sammurchana and hence acts on the vikrut vayu thereby disintegrating the samprapti.It may be also possible the drug given by the intra-uterine route may stimulate the receptor and corrects its function means Beejotsarga i.e.Ovulation.

Tikta rasa of shatapushpa causes rasraktashodhana,agnideepana and amapachan.Katurasa of it helps in rutupravartan,yonishukravishodhana.ushna virya of shatapushapa works as vatashamaka. Madhura rasa of shatapushapa acts as sthanik balya and pittashamana.

Tikta rasa of shatavari causes rasraktashodhana,agnideepana and amapachan.

Madhura rasa of shatapushapa acts as sthanik balya and pittashamana.

Shatapushpa and Shatavari is a phytoestrogen,it exerts both estrogenic and antiestrogenic activity.It acts in both high oestrogenic and low oestrogenic condition. Thus it increases the endometrial thickness.

\section{Probable Mode Of Action Of Herbal Compound-}

It also contains Shatpushpa (Anthem sowa), Shatavari (Aspergus racemosus), Trikatu (Zingiber officinale,Piper longum,Piper nigrum), Aswagandha(Withania somnifera),Jeerak (cumium cymium), Kanchnar (Bauhnia variegata),Gudmar (gymnema sylvestris), Rason(Alum sativum) increases the bioavaibility of drug in body.

The combination of drug virtue of its kashaya rasa \&laghu,ruksha guna and katu vipaka affect kapha dosha.

In anovulatory cases kapha is associated as avarana on vata.the ushna guna of drug also regulate vata and ovulation occurs. The drug mean by of dipana,pachan and shaman of grathit kapha fight against agni dushti.the increased dhatvagni promote the formation poshakansh of dhatu and updhatu (aartava)and it also suppress the increased formation of mala.Being ushna guna of dravyas they act on the derangement reduces the sheeta guna of kapha dosha and being snigdha and picchila increases these guna of kapha three guna of kapha there by increasing endometrial thickness.

\section{Conclusion-}


Both drug induces the ovulation \& increases follicular size because Shatapushpa tail \& Shatavari tail uttarbasti directly act on uterus HPO axis.

Shatapushpa and Shatavari both are contains natural phytooestrogen therefore its increases endometrial thickness \& menstrual flow.

Menstruating flow is statistically significant in group A than in group B.

The formulation proves to be an Cost effective,Herbal,Safe treatment for anovulatory menstrual cycle.

\section{AYURVEDIC TEXTS:-}

\section{Bibliography-}

[1]. Vridhajivaka, Kashyap Samhita with Vidyotini Hindi Commentary By D.S. Bahishjyaratnamani, $8^{\text {th }}$ Edition Chauckhamba Prakashan, Post Box No. 1032, Gopal Bhavan, K. 37/117, Gopal Mandir Lane, Golghar, Maidagin, Varanasi- 221001, 2002.

[2]. Sushrutaacharya, Sushrut samhitaa with sushrutavimarshini hindi commentary by Dr. Anant Ram Sharma , first edition, chaukhamba surbharati prakashan K. 37/117, Gopal Mandir Lane, Post Box No. 1129 Varanasi 221001, 2001.

[3]. Caharakaacharya, Charak Samhitaa, with 'Ayurved Deepika' commentary by Chakrapanidatt, edited by Vaidya Yadavji Trikamji Acharya, Reprint edition, Chaukhamba Surbharati Prakashan, K. 37/117, Gopal Mandir Lane, Post Box No. 1129 Varanasi 221001, 2000.

[4]. Vagbhatacharya, Ashtang Hrudaya with vidyotini commentary

[5]. by kaviraj atridev gupta, edited by vaidya yadunanda

[6]. Upadhyaya, fourteenth edition, chaukhamba Sanskrit Sansthan, Post Box No. 1139, Gopal Bhavan, K. 37/117, Gopal Mandir Lane, Golghar, Maidagin, Varanasi- 221001, 2003.

[7]. Sharangdharaacharya, Sharangdhar Samhita with dipika hind

[8]. commentary by Brahmanand Tripathi, reprint edition, Chaukhamba Surbharati prakashan, 37/117, Gopal Mandir Lane, Post Box No. 1129 Varanasi 221001, 2001.

[9]. 6. BhaavMishra, 'Bhāv Prakāś' Part-1 Vidyotini Hindi commentary by Bramhasankara Misra \& Rupalalji Vaisya, Ninth edition, Coukhambha Sanskrit Sansthan, Post Box no. 1139, Jadau Bhavan, K-37/116, Gopal Mandir Lane, Vaaraanasi- 221001 (India) 1999

[10]. Dr. Premvati. V. Tewari, Ayurvediya Prasuti Tantram Evam Stree Roga, second edition, Chaukhamba orientalia, Post Box No. 1032, Gopal Bhavan, K. 37/117, Golghar, Maidagin, Varanasi- 221001.,1996.

[11]. Bāpālāl Vaidya, Nighantu Ādarś, second edition,chaukhambha Bharat Academy, P.O.Box No. 1065, Gokul Bhawan, k 37/109, Gopal Mandir Lane, Varanasi 221001, 1997, vol I pg. 667

[12]. Priyavatt Sharma, Dravya guna Vidnyan, part II, chaukhambha Bharati Academy, P.O.Box No. 1065, Gokul Bhawan, k 37/109, Gopal Mandir Lane, Varanasi 221001, 2007

[13]. MODERN TEXTS-

[14]. Shaw's textbook of Gynaecology - Shaw Wilfred, B.I. Churchil $6^{\text {th }}$ edition.

[15]. Jeffcott's principle of gynaecology - Jeffcott Norman 2001

[16]. Textbook of Gynaecology - D.C.Dutta $3^{\text {rd }}$ editon.

[17] Goodman and Gillman's The pharmacological basis of therapeutics, edited by Alfred Goodman Gilmann, T. W. Rall, A.S.Neis and P.Taylor, volume I and II $8^{\text {th }}$ edition, Maxwell Macmillan International Edition Pergaman Press pg. no. 9 of vol I and 1051 of vol II

[18]. K.D. Tripathi, Essentials Of Medical Pharmacology, reprint updated fourth edition, Jaypee Brothers, EMCA House, 23/23B, Ansari Road, Daryaganj, New Delhi 110002, India, 2001

[19]. A.K. Nadkarni, Indian Materia and Medica, $3^{\text {rd }}$ edition, Popular press building, Tardeo Road, Bombay 400034, 1976

[20]. Anonymous, Database ommedicinal plants usedinAyurved, Published by Central Council for Research in Ayurveda and Siddha.Dept of ISM $\&$ H, Ministry of Family health and welfare, Govt of India. Vol 8,pg 419

\section{M.D.Thesis:-}

1. Vd. Pooja Shukla, Role of Uttarbasti in Aartava vyapad, BHU,1985

2 .Vd. Swati Jadhav, Prajasthapana Gana Siddha Ghrita Uttarabasti-Oral Yoag-Vandhyattva-Ovarian Factor, Jamnagar University, 2002

3. Vd. Gayatri Mishra, Role Of Shatavari Taila Uttaravasti And Combined Drug Therapy Including Shatavari Taila Uttaravasti And Some Indigenous Drugs On Vandhyavta W.S.R. To Ovulation, Jamnagar University, 2003

\section{Journals-}

Jounal Inst che India, 1973, 45, 205.

Indian J. Chem, 1979, 1713, 180.

J Indian chem. soc, 1980, 57, 417.

Indian J. Exp. Biol, 1969, 7, 250.

\section{Websites-}

1. www.wikipedia.com

2. www.emedicine.com

3 .www.herbalinformation.com

4. Mr José das Neves, University of Porto, Faculty of Pharmacy, "vaginal drug delivery system" linked in scitopics.com

5. www.chakrapaniayurveda.com

6. H Adlercreutz, Department of Clinical Chemistry, University of Helsinki, Finland. "Phytoestrogens: epidemiology and a possible role in cancer protection", 